\title{
Hepatitis B virus infection in prisons
}

\section{A seroepidemiological survey in prisoners and attending staff}

\author{
BY M. CHIARAMONTE, R. TRIVELLO*, G. RENZULLI*, L. ZAMPIERI, \\ A. FANECCO, A. FLOREANI AND R. NACCARATO \\ Clinica Medica I, Cattedra di Gastroenterologia and * Istituto di Igiene, \\ Università di Padova, Italy
}

(Received 16 September 1981; accepted 8 February 1982)

\section{SUMMARY}

Prisoners and attending staff from six houses of detention were screened for serum $\mathrm{HBsAg}$, antiHBs, antiHBc and transaminases. Both prisoners and warders showed an increased prevalence of $\mathrm{HBV}$ serum markers with respect to age- and sex-matched general population control groups. The HBsAg carrier rate was $6.7 \%$ in prisoners and $6.6 \%$ in staff. Sixty-five per cent of the HBsAg-positive subjects were antiHBe-positive. When the blood samples were taken, all the $\mathrm{HBsAg}$-positive subjects were asymptomatic; transaminases were normal in $80 \%$ and only slightly elevated in $20 \%$.

Illicit drug abuse was found to be a relevant risk factor for $\mathrm{HBV}$ infection among prisoners under 35 years of age, but not in the older group, whereas no correlation emerged between presence of HBV serum markers and tattoos or admitted homosexuality. A high prevalence of HBV serum markers was also found among young warders who had been in service for a short time: most of them, however, come from areas of Italy with a particularly elevated HBV circulation.

Although the results suggest that many of the HBV infections are not recently acquired within the institution, this survey confirms that prisons should be regarded as high risk areas for HBV infection, both for prisoners and warders.

\section{INTRODUCTION}

Closed institution residents carry an increased risk of type B hepatitis (Szmuness \& Prince, 1971). The HBV infection rate is particularly elevated among parenteral drug abusers (Blanck, Ream \& Conrad, 1979), homosexual males (Szmuness et al. 1975) and prostitutes (Papaevangelou et al. 1974). In the United States the HBsAg carrier rate was found to be higher among paid blood donors coming from penal institutions than among volunteer blood donors (Kliman, 1971; Muniz, Malyska \& Levin, 1971).

All these observations suggest that among prisoners there should be an increased incidence of HBV infection. However, few data are reported in the literature 
(Watson, Watts \& Nelson, 1973; Koplan, Walker \& Berquist, 1978) and no study has included research of all the $\mathrm{HBV}$ serum markers now available.

In order to throw light on the prevalence of $\mathrm{HBV}$ infection among prisoners and in an attempt to evaluate the role of this type of institutionalization in the spread of $\mathrm{HBV}$, a seroepidemiological survey was carried out in several houses of detention in Veneto, a region of north-east Italy.

\section{MATERIAL AND METHODS}

\section{Study protocol}

Six houses of detention were included in the study. Both prisoners and attending staff were surveyed. From each consenting subject blood was collected for HBV serum marker (HBsAg, antiHBs, antiHBc) detection and transaminase assay. Information about age, length of imprisonment or employment, history of liver disease, parenteral drug abuse, sexual habits, exposure to parenteral HBV contamination (blood transfusions, major surgery, dental care, injections, tattooing) was recorded on a card accompanying each serum. The interviews and the collection of blood were carried out by a member of the prison medical and nursing staff.

Serum specimens sent to our laboratory for $\mathrm{HBsAg}$, antiHBs and antiHBc detection were stored at $-20^{\circ} \mathrm{C}$ until tested by radioimmunoassay using commercially available kits (Abbott Laboratories, Chicago, Illinois) according to the manufacturer's instructions. When the amount of serum allowed it, HBsAgpositive samples were tested for $\mathrm{HBeAg}$ /antiHBe by RIA (supplied by Abbott Laboratories). This test was not included in the original protocol of the study. Transaminase assays were done in different local laboratories using conventional methods.

Statistical analysis was done using the $\chi$-square test.

\section{Study groups}

\section{Prisoners}

Three hundred and eighty-five subjects, corresponding to a proportion ranging from 40 to $65 \%$ of the actual population of each house of detention, were studied. Two hundred and twenty-five were males and 48 females. Their ages ranged from 15 to 76 years, with mean ages of $31 \pm 5 \cdot 5$ and $32 \pm 5 \cdot 6$ years for males and females respectively.

Staff

Two hundred and fifty-five attending personnel (225 males and 30 females) corresponding to $70 \%$ of the total employees (warders, clerical and nursing staff) were studied. Their ages ranged from 19 to 75 years. Of the male staff tested, $68 \%$ were less than 35 years of age. This group consisted mainly of warders, who usually start service at the age of 18-20. Most members of the female staff had domestic or nursing jobs; their mean age $(\mathbf{4 4 . 9 \pm 6 . 7}$ years) was higher than that of males $(31 \cdot 5 \pm 5 \cdot 6$ years $)$. 
Table 1. Prevalence of $H B V$ markers in houses of detention

\begin{tabular}{|c|c|c|c|c|c|}
\hline & & $\begin{array}{c}\text { HBsAg } \\
( \pm \text { antiHBc) }\end{array}$ & $\begin{array}{c}\text { AntiHBs } \\
( \pm \text { antiHBc })\end{array}$ & $\begin{array}{l}\text { AntiHBc } \\
\text { alone }\end{array}$ & Total HBV \\
\hline & tested & Number $(\%)$ & Number $(\%)$ & Number (\%) & Number (\%) \\
\hline \multicolumn{6}{|l|}{ Prisoners } \\
\hline Males & 337 & $24(7 \cdot 1)^{* *}$ & $111(32 \cdot 9)^{* *}$ & $36(10 \cdot 6)^{* *}$ & $171(50 \cdot 7)^{* *}$ \\
\hline Females & 48 & $2(4 \cdot 1) \dagger$ & $18(37 \cdot 5)^{* *}$ & $6(12 \cdot 5)^{* *}$ & $26(54 \cdot 1)^{* *}$ \\
\hline Total & 385 & $26(6 \cdot 7)^{* *}$ & $129(33.5)^{* *}$ & $42(10.9)^{* *}$ & $197(51 \cdot 1)^{* *}$ \\
\hline \multicolumn{6}{|l|}{ Staff } \\
\hline Males & 225 & $16(7 \cdot 0)^{* *}$ & $75(33 \cdot 3)^{* *}$ & $17(7 \cdot 5) \dagger$ & $108(48 \cdot 0)^{* *}$ \\
\hline Females & 30 & $1(3 \cdot 3) \dagger$ & $10(33 \cdot 3)^{* *}$ & $2(6 \cdot 6) \dagger$ & $13(43 \cdot 3)^{* *}$ \\
\hline Total & 255 & $17(6 \cdot 6)^{* *}$ & $85(33 \cdot 3)^{* *}$ & $19(7 \cdot 4)^{*}$ & $121(47 \cdot 4)^{* *}$ \\
\hline \multicolumn{6}{|c|}{ Civilian workers } \\
\hline Males & 57 & $3(5 \cdot 2) \dagger$ & $10(17 \cdot 5) \dagger$ & $7(12 \cdot 2)^{* *}$ & $20(35 \cdot 5) \dagger$ \\
\hline \multicolumn{6}{|c|}{ General population } \\
\hline Males & 927 & $28(3 \cdot 0)$ & $161(17 \cdot 3)$ & $43(4 \cdot 6)$ & $232(25 \cdot 0)$ \\
\hline Females & 971 & $19(1.9)$ & $133(13 \cdot 6)$ & $41(4 \cdot 2)$ & $193(19 \cdot 8)$ \\
\hline Total & 1898 & $47(2 \cdot 4)$ & $294(15 \cdot 4)$ & $84(4 \cdot 4)$ & $425(22 \cdot 3)$ \\
\hline
\end{tabular}

Statistical analysis: studied group vs respective control group (general population): $\dagger$ not significant; ${ }^{*} P<0.05 ;{ }^{* *} P<0.01$ : staff vs prisoners: differences not statistically significant.

\section{Civilian workers}

From one prison we received the sera and the cards of 57 civilian workers (all males, mean age $46.9 \pm 6 \cdot 8$ years) who were also included in the screening as they had been working together with prisoners in a workshop inside the house of detention for many years.

\section{Controls}

As controls we used 1898 subjects (927 males and 971 females) of the same age range who had been tested for $\mathrm{HBsAg}$, antiHBs, antiHBc during an epidemiological survey carried out by the same laboratory on the general population of Padova and its district. The sera of these control subjects were collected on the occasion of health certificate requests or hospital admission for minor surgery, for childbirth or as casualties and were tested by the same methods as study groups.

\section{RESULTS}

\section{$H B V$ infection}

The overall prevalence of $\mathrm{HBV}$ infection (evaluated on the basis of serum positivity for at least one of the following: $\mathrm{HBsAg}$, antiHBs, antiHBc) was $51 \cdot 1 \%$ among prisoners and $\mathbf{4 7 . 4} \%$ among staff, while the prevalence in the worker groups was not significantly different from that observed in age-matched male controls from the same town ( $35 \%$ vs $25 \%$ ) (Table 1 ).

The HBsAg prevalence, higher in males than in females, was very similar between prisoners and warders in both males $(7 \cdot 1 \%$ in prisoners vs $7.0 \%$ in staff $)$ and females $(4 \cdot 1 \%$ in prisoners vs. $3.3 \%$ in staff $)$. In all cases except four the $\mathrm{HBsAg}$ 
Table 2. $H B V$ marker prevalence according to age and sex in prisoners

\begin{tabular}{|c|c|c|c|c|}
\hline & $\begin{array}{c}\text { HBsAg } \\
( \pm \text { antiHBc) }\end{array}$ & $\begin{array}{c}\text { AntiHBs } \\
( \pm \text { antiHBc })\end{array}$ & $\begin{array}{l}\text { AntiHBc } \\
\text { alone }\end{array}$ & Total HBV \\
\hline & Number $(\%)$ & Number $(\%)$ & Number $(\%)$ & Number $(\%)$ \\
\hline \multicolumn{5}{|l|}{ Males } \\
\hline $\begin{array}{r}<35 \text { years } \\
(N=253)\end{array}$ & $20(7 \cdot 9)$ & $76(30 \cdot 0)$ & $26(10 \cdot 2)$ & $122(48 \cdot 2)$ \\
\hline $\begin{array}{c}>35 \text { years } \\
(N=84)\end{array}$ & $4(4 \cdot 7)$ & $35(41 \cdot 6)$ & $10(11.9)$ & $49(58 \cdot 3)$ \\
\hline \multicolumn{5}{|l|}{ Females } \\
\hline $\begin{array}{c}<35 \text { years } \\
(N=29)\end{array}$ & - & $8(27 \cdot 5)$ & $3(10 \cdot 3)$ & $11(37 \cdot 9)$ \\
\hline $\begin{array}{c}>35 \text { years } \\
(N=19)\end{array}$ & $2(10 \cdot 5)$ & $10(52 \cdot 6)$ & $3(15 \cdot 7)$ & $15(78.9)$ \\
\hline
\end{tabular}

positivity was associated with antiHBc positivity. AntiHBs without antiHBc was found in nine subjects only.

Thirty-two HBsAg-positive serum samples (22 from prisoners and 10 from warders) were tested for $\mathrm{HBeAg}$ /antiHBe. Six of $32(18.7 \%$ ) were $\mathrm{HBeAg}$-positive and 21 of $32(65 \cdot 6 \%)$ were antiHBe-positive. Results were negative both for $\mathrm{HBeAg}$ and antiHBe in 5 cases. The proportion of $\mathrm{HBeAg}$-positive sera in warders was less than that of prisoners $(10 \%$ vs $22 \%)$.

Of the $44 \mathrm{HBsAg}$-positive subjects, the transaminases of $35(79.5 \%)$ were normal and of $9(20.4 \%)$ were slightly elevated. In no case was the increase more than three times the normal value.

\section{Analysis of risk factors}

\section{Prisoners}

Seventy-five per cent of male and $60 \%$ of female prisoners studied were under 35 years of age. The prevalence of $\mathrm{HBsAg}$-positive subjects decreases and the prevalence of antiHBs increases with age in both males and females (Table 2).

Of the younger age group, 59/282 subjects (20.9\%) admitted drug abuse $: 79 \cdot 6 \%$ of these had evidence of HBV infection, whereas the HBV marker prevalence in those who did not declare drug addiction was $38.3 \%$. The relative risk factor was 6.2. Only one subject over 35 years of age declared drug abuse.

Eighteen $(7 \cdot 1 \%)$ of 253 males under 35 years of age admitted homosexual practice: 11 of $20(55 \%)$ of these had evidence of $\mathrm{HBV}$ infection.

Forty-three per cent of the younger males and $14.2 \%$ of the older group were tattooed: the relative risk calculated in the two groups together was 1.3.

\section{Personnel}

The prevalence of $\mathrm{HBV}$ infection was shown to increase with advancing age in the female staff, whereas in males the $\mathrm{HBsAg}$ or antibody prevalences of the younger group were similar to those of the older age group (Table 3). As there were several discrepancies in the answers to the questionnaires it was not possible to 
Table 3. HBV marker prevalence according to age and sex in personnel

\begin{tabular}{|c|c|c|c|c|}
\hline & $\begin{array}{c}\text { HBsAg } \\
( \pm \text { antiHBc) }\end{array}$ & $\begin{array}{c}\text { AntiHBs } \\
( \pm \text { antiHBc })\end{array}$ & $\begin{array}{l}\text { AntiHBc } \\
\text { alone }\end{array}$ & Total HBV \\
\hline & Number $(\%)$ & Number $(\%)$ & Number $(\%)$ & Number $(\%)$ \\
\hline \multicolumn{5}{|l|}{ Males } \\
\hline $\begin{array}{r}<35 \text { years } \\
(N=157)\end{array}$ & $11(7 \cdot 0)$ & $59(37 \cdot 5)$ & $7(4 \cdot 4)$ & $77(49)$ \\
\hline $\begin{array}{c}>35 \text { years } \\
(N=68)\end{array}$ & $5(7 \cdot 3)$ & $16(23 \cdot 5)$ & $10(14 \cdot 7)$ & $31(45 \cdot 5)$ \\
\hline \multicolumn{5}{|l|}{ Females } \\
\hline $\begin{array}{c}<35 \text { years } \\
(N=10)\end{array}$ & - & $1(10)$ & $1(10)$ & $2(20)$ \\
\hline $\begin{array}{c}>35 \text { years } \\
(N=20)\end{array}$ & $1(5)$ & $9(45 \cdot 0)$ & $1(5)$ & $11(55)$ \\
\hline
\end{tabular}

make a statistical correlation between the HBV serum marker prevalence and the length of employment; however, since warders generally start their service at the age of 18-20 years, one can assume that the correlation with age reflects a correlation with duration of employment in the prison environment.

Two subjects only admitted illicit drug abuse, none said he was homosexual.

\section{DISCUSSION}

The results of this survey confirm that prisoners can be considered a high prevalence group for HBV infection. Most of the prisoners surveyed (probably more than those who confessed it) practised illicit drug abuse and several admitted to homosexual relations: both practices are well-recognized risk factors in HBV transmission (Blanck et al. 1979; Szmuness et al. 1975). Furthermore, tattoos are very popular among these people: this habit can also partially contribute to the HBV spread (Sterner et al. 1971).

The prison environment also seems to constitute a high-risk situation for people working in it. The increase of antiHBs prevalence according to age, observed in females, may be consistent with nursing activity in HBV medium-risk areas. However, the high prevalence of infection observed in male staff, even in the group of young people with only a short term of service, was unexpected. This finding might indicate that warders contract the $\mathrm{HBV}$ infection inside the prison during their first months of employment. However, in interpreting these data we must consider that (1) most of the warders come from areas of Italy (such as Sardinia) with a particularly elevated HBV circulation (Ceppellini et al. 1970), and (2) an increased prevalence of jaundice among them has not been reported. It is therefore possible that the high prevalence of HBV markers in young warders may precede their employment. Further epidemiological studies are needed to verify this hypothesis.

The majority of HBsAg carriers (both prisoners and warders) were found to be antiHBe-positive, indicating, on the one hand longstanding infection (Hoofnagle, 
1980), and on the other low infectivity (Alter et al. 1976) and, therefore, low risk of HBV spread among contacts. This finding further supports the hypothesis that many of the HBV infections were not recently acquired within the institution.

In conclusion, prisons should be regarded as areas of relatively high HBV circulation, both for prisoners and for attending staff. However, while in other communities or in the household the spread is directly correlated to the proportion of $\mathrm{HBeAg}$-positive $\mathrm{HBsAg}$ carriers and to the duration of close cohabitation with them, in prisons the institutionalization may act mainly as a concentration of individuals already highly exposed to HBV because of their social or ethnic background and/or their life style. However, some of these risk factors may be enhanced by enforced cohabitation in prisons.

This study was commissioned by the Veneto Regional Committee for the Study and Prevention of Viral Hepatitis and financially supported by the Regione Veneto.

\section{REFERENCES}

Alter, H. J., Seeff, L. B., Kaplan, P. M., McAuliffe, V. J., Wright, E. C., Gerin, J. L., Purcell, R. L., Holland, P. V. \& Zimmerman, H. J. (1976). Type B hepatitis: the infectivity of blood positive for e antigen and DNA polymerase after accidental needlestick exposure. New England Journal of Medicine 295, 909-913.

Blanck, R. R., Ream, N. \& Conrad, M. (1979). Hepatitis B antigen and antibody in heroin users. American Journal of Gastroenterology 71, 164-167.

Ceppellini, R., Bedarida, G., Carbonara, A. O., Trinchieri, G. \& Filippi, G. (1970). High frequency and familial clustering of $\mathrm{Au}$ antigen in some Italian populations. In Antigene Australia ed epatite virale, pp. 53-74. Torino: Convegni Farmitalia, Minerva Medica.

Hoofnagle, J. H. (1980). Hepatitis B surface antigen (HBsAg) and antibody (antiHBs). In Virus and the Liver (ed. L. Bianchi, W. Gerok, K. Sickinger and G. A. Stalder), pp. 27-37. M.T.P. Press C.T.D.

Kliman, A. (1971). Australia antigen in volunteer and paid blood donors. New England Journal of Medicine 284, 109.

Koplan, J. P., Walker, J. A. \& Berquist, K. R. (1978). Prevalence of Hepatitis B surface antigen and antibody at a state prison in Kansas. Journal of Infectious Diseases 137, 505-506.

Muniz, F. J., Malyska, H. \& Levin, W. C. (1971). Au antigen in blood from prisoners. New England Journal of Medicine 284, 501-502.

Papaevangelou, G., Trichopoulos, D., Kremastinou, T. \& Papoutskis, G. (1974). Prevalence of hepatitis B antigen and antibody in prostitutes. British Medical Journal ii, 256-258.

Shikata, T., Karasawa, T., Abe, K., Urawa, T., Suzuki, H., Oda, T., Imai, T., Mayumi, M. \& Moritsugu, Y. (1977). Hepatitis Be antigen and infectivity of hepatitis B virus. Journal of Infectious Diseases 136, 571-576.

Sterner, G., Agell, B. O., Gerzen, P. \& Berg, R. (1971). Hepatitis with Australia antigen after tattooing. Scandinavian Journal of Infectious Diseases 3, 109-112.

Szmuness, W. \& Prince, A. M. (1971). The epidemiology of serum hepatitis (SH) infections: a controlled study in two closed institutions. American Journal of Epidemiology 94, 585-595.

Szmuness, W., Much, M. I., Prince, A. M., Hoofnagle, J. H., Cherubin, C. E., Harley, E. J. \& BLOCK, G. H. (1975). On the role of sexual behaviour in the spread of hepatitis B infection. Annals of Internal Medicine 83, 489-495.

Watson, P. G., Watts, J. R. \& Nelson, M. (1973). The incidence of Australia antigen and antibody in male prisoners of two Sydney penitentiaries. The Medical Journal of Australia ii, 421-423. 